\title{
Enrichment Capacity of Lead in Water by Aquatic Plants
}

\author{
Qing Ma', Yue Peng' ${ }^{2 *}$ Jiquan Zhang ${ }^{1}$, Meichen $\mathbf{J i}^{1}$ \\ ${ }^{1}$ School of Environment, Institute of Natural Disaster Research, Northeast Normal University, Changchun, China \\ ${ }^{2}$ College of Chemistry and Environmental Protection Engineering, Southwest Minzu University, Chengdu, China
}

Received: 18 April 2018

Accepted: 10 June 2018

\begin{abstract}
Phytoremediation is a promising, low-cost and environmentally friendly technology. By simulating different concentrations of $\mathrm{Pb}, \mathrm{Pb}+\mathrm{Zn}$ and $\mathrm{Pb}+\mathrm{EDTA}$ in aqueous solutions, taking Acorus calamus, Eichhornia crassipes and Iris tectorum as experimental material, hydroponics was used to study the enrichment of aquatic plants to $\mathrm{Pb}$ in water under different conditions. The results show that Eichhornia crassipes has the best bioconcentration capacity, Acorus calamus has good bioconcentration and Iris tectorum has weak bioconcentration. The bioconcentration factors (BCFs) are more than 1 and the $\mathrm{BCFs}$ of the underground parts are greater than that of the aboveground parts. However, the translocation factors (TFs) are less than 1. The presence of $\mathrm{Zn}$ enhances the enrichment of the aquatic plants to $\mathrm{Pb}$. The presence of EDTA reduces the enrichment, but promotes the transfer of $\mathrm{Pb}$ from underground parts to aboveground parts. All of the conclusions can provide reference for the application of aquatic plants for Phytoremediation of $\mathrm{Pb}$.
\end{abstract}

Keywords: lead pollution; combined pollution; wastewater; phytoremediation

\section{Introduction}

With the rapid development in urbanization and industrialization, heavy metals have been widely used in industrial processes. Improper treatment of municipal sewage or industrial wastewater can easily lead to the increase of heavy metals in water. The heavy metal pollution of water resources is a key problem that has adverse effects on human beings, animals and plants [1]. Although heavy metals are natural components of the environment, excessive human activities have altered their geochemical cycles and biochemical balances [2]. Heavy metals are non-biodegradable and persistent

*e-mail: pengyue2000@163.com environmental contaminants [3]. When heavy metals enter the bodies of animals and humans through the food chain, they eventually pose a risk to the environment and human health [4-6].

Lead is one of the most common heavy metal pollutants with a very high toxicity level. The toxicity levels of lead, mercury, arsenic and cadmium as listed by the Agency for Toxic Substances and Disease Registry (ATSDR), ranking first, second, third and sixth, respectively [7, 8]. When an excessive amount of lead is absorbed in the human body, it affects the nervous system through the blood and causes IQ reduction of the brain. In addition, lead can accumulate in the human body over time and eventually affects the kidneys, hematopoietic system, reproductive system and cardiovascular system [9]. 
The three most common methods used to remediate heavy metal-contaminated water are physical remediation, chemical remediation and bioremediation [10]. However, the physical and chemical methods are costly, require trained staff and may produce secondary pollutants [11-14]. On the contrary, phytoremediation is a low-cost and environmentally friendly method [15]. It is a technology that uses plants and microorganisms to remediate partially or completely selected contaminants from soils, sludge, sediments, wastewater and groundwater [2, 16]. Phytoremediation techniques include plant extraction, plant filtration, plant stabilization, plant volatilization and plant degradation [17]. Wetland plants are biological filters that can absorb heavy metals from sediments and water [18]. High element absorption and high biomass make aquatic plants the best species for remediating a heavy metalpolluted environment [19].

At present, much research is underway on phytoremediation of heavy metals in contaminated soil, and the removal of heavy metals from wastewater is gradually becoming a research hotspot. Bingöl et al. [20] studied the phytoremediation and biosorption potential of Lythrum salicaria L. for nickel removal from aqueous solution. $\mathrm{Lu}$ et al. [21] studied the phytoremediation potential of eight aquatic plants for copper contamination. Li et al. [22] studied the interaction between Alternaria helix philoxeroides (Mart.) Griseb and cadmium movement in aquatic environment through hydroponic stress experiments, and found that $A$. philoxeroides could be used to remediate cadmium-contaminated water. Dogan et al. [23] bred Ceratophyllum demersum L. using tissue culture techniques, and studied the potential for Ceratophyllum demersum $\mathrm{L}$. to bioaccumulate $\mathrm{Pb}$ and $\mathrm{Cd}$. The result showed that Ceratophyllum demersum L. could be used to remediate $\mathrm{Cd}$ - and $\mathrm{Pb}$-contaminated aquatic environments. In this study we conducted a simulation experiment to compare the growth of aquatic plants and their ability to uptake lead in different concentrations of lead-alone stress, $\mathrm{Pb}-\mathrm{Zn}$ combined stress and $\mathrm{Pb}$-EDTA combined stress (with EDTA as a chelating agent).

\section{Material and Methods}

\section{Experimental Design}

The collected aquatic plants were first washed with tap water and left for 7 days. The plants were again washed with deionized water. $\mathrm{Pb}\left(\mathrm{NO}_{3}\right)_{2}, \mathrm{Zn}\left(\mathrm{NO}_{3}\right)_{2}$ and Edetate disodium were dissolved in deionized water to prepare the mother liquor of $\mathrm{Pb}^{2+}, \mathrm{Zn}^{2+}$ and EDTA of $50 \mathrm{mg} / \mathrm{L}$ in $1000 \mathrm{~mL}$ volumetric flask. Lead alone, $\mathrm{Pb}-\mathrm{Zn}$ and $\mathrm{Pb}$-EDTA solutions with different initial concentrations were prepared in glass bottles of $1 \mathrm{~L}$ volume. After adding $5 \mathrm{~mL}$ nutrient solution to each bottle, the treated aquatic plants were placed in those bottles, with three plants in a group. The water level line was marked after finishing the above steps. The research objects were left in an open air room, with adequate light and ventilation, and cultured at ambient temperature. For lead-alone stress, the concentration of lead in the solution was 5, 10, 50, 100 and $500 \mathrm{mg} / \mathrm{L}$ in turn. For $\mathrm{Pb}-\mathrm{Zn}$ combined stress, the concentration of lead in solution was $50 \mathrm{mg} / \mathrm{L}$, and the concentration of $\mathrm{Zn}$ was 5, 10, 50, 100 and $500 \mathrm{mg} / \mathrm{L}$ in turn. For PbEDTA combined stress, lead and EDTA in solution were formulated according to a 1:1 ratio, followed by $5,10,50,100$ and $500 \mathrm{mg} / \mathrm{L}$ in turn. Meanwhile, the concentration of Acorus calamus on three medium-low concentration lead-containing wastewater was studied. The same as the previous preparation method, the concentrations of $\mathrm{Pb}, \mathrm{Zn}$ and EDTA changed to 5, 10, 20 and $50 \mathrm{mg} / \mathrm{L}$.

\section{Analysis of Heavy Metal Elements Content}

The growth response of the plants needs to be observed and recorded. $50 \mathrm{~mL}$ water samples were taken after every 10 days. In the meantime, deionized water was added to the glass bottle until it reached the water level line marked earlier. After that, the water samples were filtered with $0.45 \mu \mathrm{m}$ filter membrane. The content of $\mathrm{Pb}$ was measured by flame atomic absorption spectrometry.

After 60 days of cultivation, the aquatic plants were taken out, rinsed with tap water and rinsed three times with deionized water. The plants were divided into aboveground and underground parts, and their fresh weight was recorded. The aquatic plants were then put in the oven for drying and the dried samples were weighed with an electronic balance. A constant weight sample was ground into a powder with a mortar. The aboveground parts and the underground parts were accurately weighed $0.4000 \pm 0.0001 \mathrm{~g}$ by quartering method. First they were put into a $5 \mathrm{~mL}$ crucible and carbonized powder was obtained in a low-temperature electric furnace. Then it was transferred in a crucible in the muffle furnace ashing at $500^{\circ} \mathrm{C}$. Then nitric acid solution of 1:1 (10 mL) and 1 drop of hydrogen peroxide solution were added and passed through the $0.45 \mu \mathrm{m}$ membrane. The content of $\mathrm{Pb}$ was measured by flame atomic absorption spectrometer thereafter.

\section{Data Analysis}

Double factor variance analysis was used to compare the effects of $\mathrm{Pb}$ concentration and culture time on the enrichment of $\mathrm{Pb}$ under $\mathrm{Pb}, \mathrm{Pb}-\mathrm{Zn}$ combined and $\mathrm{Pb}$ EDTA combined solutions. Additionally, this analysis was used to compare the effects of different plant species on $\mathrm{Pb}$ enrichment ability under different $\mathrm{Pb}$ treatments. The data were analyzed by MINITAB 17.

The bioconcentration factors $(\mathrm{BCFs})$ and translocation factors (TFs) were used to assess the potential of plants for removal of heavy metals [24]. BCFs can be used to assess the ability of plants to 
accumulate heavy metals from water. TFs can be used to assess the ability of elements to transfer in plants, and it is the proportion of one element concentration in two parts of the plant [25]. They have been proved by many studies [26-31]. The $\mathrm{K}_{\mathrm{pb}}$ value characterizes the effect of combined stress on plant $\mathrm{Pb}$ accumulation.

$\mathrm{BCFs}=\left(\mathrm{C}_{\text {underground }}\right.$ or $\left.\mathrm{C}_{\text {aboveground }}\right) / \mathrm{C}_{\text {water }}$

$\mathrm{TFs}=\mathrm{C}_{\text {aboveground }} / \mathrm{C}_{\text {underground }}$

$\mathrm{K}_{\mathrm{pb}}=\mathrm{C}_{\text {combined }}^{\text {aboveground }} / \mathrm{C}_{\text {single }}$

$\mathrm{C}^{\mathrm{pb}}$ underground and $\mathrm{C}$ aboveground indicate the concentration of heavy metals in the plants underground parts and aboveground parts, respectively $\left(\mathrm{mg} \mathrm{L}^{-1}\right) . \mathrm{C}_{\text {water }}$ represents the concentration of heavy metals in the solution $\left(\mathrm{mg} \mathrm{L}^{-1}\right) . \mathrm{C}_{\text {combined }}$ and $\mathrm{C}_{\text {single }}$ represent the concentration of heavy metals in the plants under combined stress and single heavy metal stress, respectively $\left(\mathrm{mg} \mathrm{L}^{-1}\right)$.

\section{Results and Discussion}

\section{Growth Response}

In the process of aquatic plant culture, plant biomass, plant root length and plant height have been changed. Taking Acorus calamus as an example, only the change rate of biomass and root length are listed, because the change of plant height mainly shows the increase of plant root length (Fig. 1). The roots of three

a)

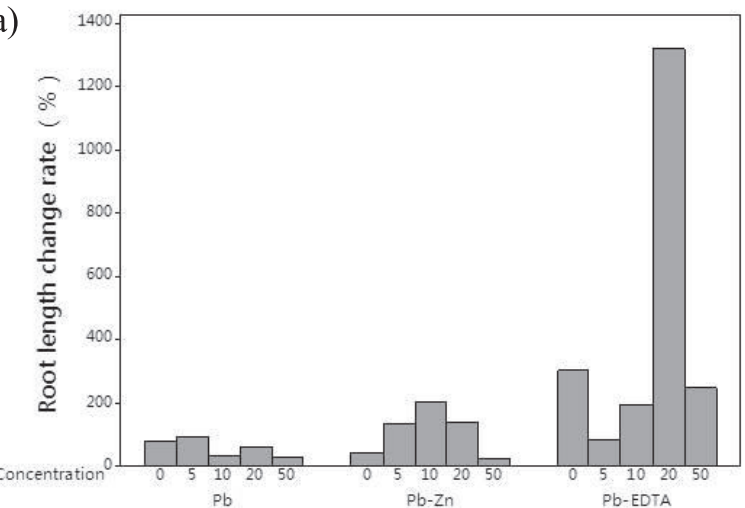

b)

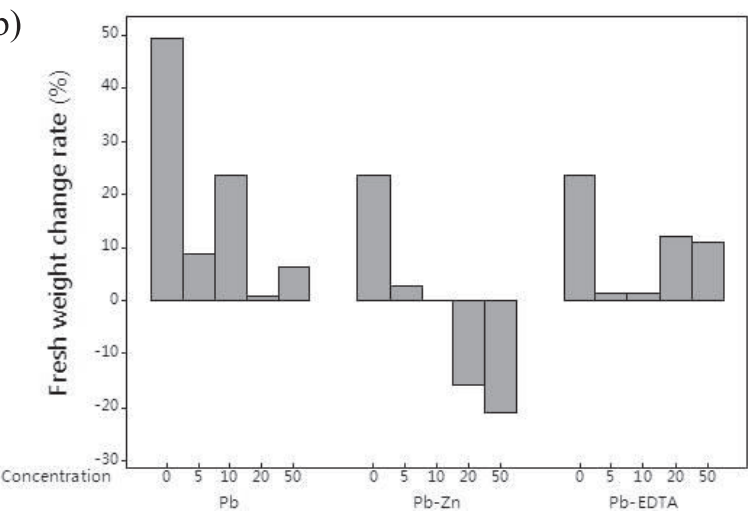

Fig. 1. The change rate of root length and fresh weight of Acorus calamus. after 60 days of culture. experimental groups were elongated after 60 days of culture. In general, the rate of root length change of plants in the Pb-EDTA combined stress environment is much larger than the ones in $\mathrm{Pb}$ alone stress and $\mathrm{Pb}-\mathrm{Zn}$ combined stress environment. In addition, for biomass growth rate, both plants growing in $\mathrm{Pb}$-alone stress and $\mathrm{Pb}$-EDTA combined stress environment had increased biomass, which indicates that the low concentration of lead can increase the metabolism of plants. However, in the experimental group contaminated by $\mathrm{Pb}-\mathrm{Zn}$, the biomass of plants was increased under low $\mathrm{Zn}$ concentration $(\leq 5 \mathrm{mg} / \mathrm{L})$ and the biomass of plants was decreased under medium-low $\mathrm{Zn}$ concentration $(\geq 10 \mathrm{mg} / \mathrm{L})$. It can be seen that when $\mathrm{Zn}$ concentration is high, the combined effect of lead and zinc can inhibit the growth and metabolism of plants.

\section{Traits of Plant Injury}

Aquatic plants can purify lead-contaminated wastewater by absorbing and enriching $\mathrm{Pb}$. When $\mathrm{Pb}$ concentration exceeds a certain threshold, plant growth and metabolism may be affected and even plant death may occur [10, 32]. When exogenous heavy metal pollutants enter into the water, plants can absorb them through root metabolism. Some remain in the roots, while others move to the aboveground parts with the transpiration in plants and accumulate in the stems and leaves of the plants, thereby harming them [33].

Root decay phenomenon: On the $10^{\text {th }}$ day of culture, the number and growth of new shoots of Acorus calamus was less and slower in the experimental group than the one in the control group (Fig. 2). In the late stage of cultivation (30 days), $\mathrm{Pb}$-free wastewater had more shoots and longer roots and there was no decay found. In contrast, the plant roots in $\mathrm{Pb}$-containing wastewater started to decay, and roots in $\mathrm{Pb}-\mathrm{Zn}$ contaminated water were severely damaged. In the later stage of culture, the root of Eichhornia crassipes had a slight decay phenomenon, and the root decay of Iris tectorum was the worst.

Yellowing effect on Leaves: On the $3^{\text {rd }}$ day of culture, there was a slight yellowing sign on the edge of leaves. On the $30^{\text {th }}$ day, the leaves were partially yellowed. On the $60^{\text {th }}$ day, some of Acorus calamus turned yellow in the experimental group of $\mathrm{Pb}$-alone stress and $\mathrm{Pb}$ EDTA combined stress, and all of the Acorus calamus leaves were yellowed in the experimental group under $\mathrm{Pb}-\mathrm{Zn}$ combined stress. Moreover, with the increase of concentration of $\mathrm{Pb}$ and $\mathrm{Zn}$ in the solution, the yellowing effect of the plant was more obvious. Eichhornia crassipes in the latter part of the cultivation showed slight leaf yellowing effect, and Iris tectorum early in the culturing showed damage symptoms. There are two reasons explaining chlorosis phenomenon in plants. The toxicity of lead affects photosynthesis, and synthesis of chlorophyll degradation can reduce or increase, thus changing the plant carotenoid and chlorophyll ratio, which results in plant leaf chlorosis [34]. Another 

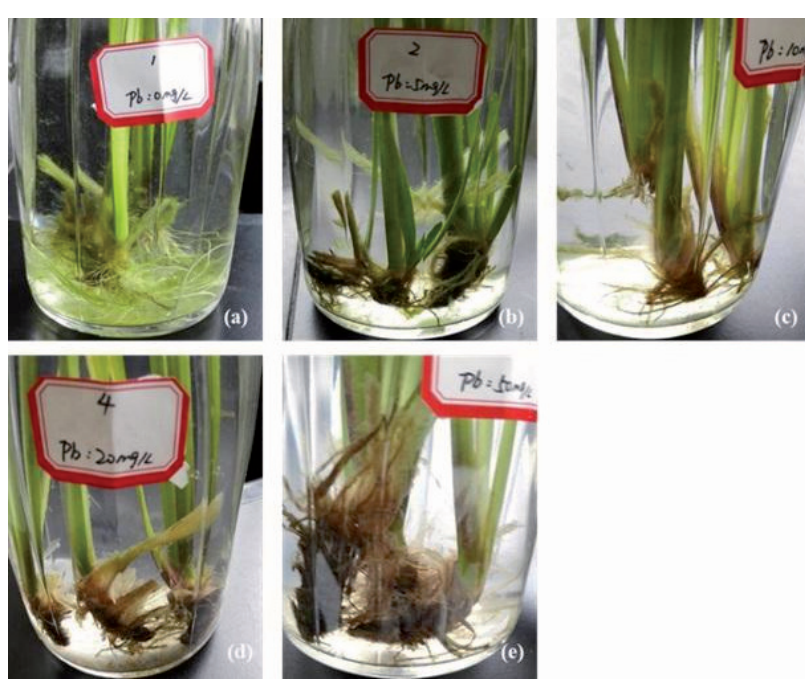

Fig. 2. Comparison of root elongation of Acorus calamus after 10 days of culture: a) control group b-e) experimental group, the concentration of lead was 5,10,20,50 (mg L-1) in turn.

reason is that iron is an activator of some enzymes of chlorophyll synthesis. Lead accumulation in plants affects the absorption of iron and prevents the synthesis of chlorophyll, leading to a yellowing of plant leaves [35].

\section{Factors Affecting the Enrichment of Lead in Plants}

Double-factor variance analysis showed that culture time and different concentrations of lead and combined stress treatment had significant effects on $\mathrm{Pb}$ accumulation in plant tissues $(\mathrm{P}<0.05)$ (Table 1). For the underground parts and the whole plant, the accumulation of $\mathrm{Pb}$ was significantly influenced by the initial concentration of $\mathrm{Pb}$ and the species of plants $(\mathrm{P}<0.05)$ (Table 2). However, for the aboveground parts, the initial concentration of $\mathrm{Pb}$ and the species of plants could not be considered to have significant effects on the accumulation of $\mathrm{Pb}(\mathrm{P}>0.05)$ (Table 2).

Table 1. Double-factor variance analysis results of concentration and culture time.

\begin{tabular}{|c|c|c|c|}
\hline Pollution & Variable & $\mathrm{F}$ & $\mathrm{P}$ \\
\hline \multirow{2}{*}{ Single Pb pollution } & $\mathrm{Pb}$ concentration & 5.60 & 0.005 \\
\cline { 2 - 4 } & Culture time & 18.65 & $<0.001$ \\
\hline $\begin{array}{c}\text { Pb-Zn combined } \\
\text { pollution }\end{array}$ & Zn concentration & 4.95 & 0.009 \\
\cline { 2 - 4 } & Culture time & 126.33 & $<0.001$ \\
\hline $\begin{array}{c}\text { Pb-EDTA combined } \\
\text { pollution }\end{array}$ & EDTA concentration & 30.88 & $<0.001$ \\
\cline { 2 - 4 } & Culture time & 6.33 & 0.003 \\
\hline
\end{tabular}

Table 2. Double-factor variance analysis results of concentration and plant species.

\begin{tabular}{|c|c|c|c|}
\hline Plant parts & Variable & $\mathrm{F}$ & $\mathrm{P}$ \\
\hline \multirow{2}{*}{ Aboveground parts } & Pb concentration & 2.63 & 0.114 \\
\cline { 2 - 4 } & Plant species & 1.24 & 0.340 \\
\hline \multirow{2}{*}{ Underground parts } & Pb concentration & 5.27 & 0.022 \\
\cline { 2 - 4 } & Plant species & 5.74 & 0.028 \\
\hline \multirow{2}{*}{ Whole plant } & Pb concentration & 6.54 & 0.012 \\
\cline { 2 - 4 } & Plant species & 4.65 & 0.046 \\
\hline
\end{tabular}

\section{Plant Accumulation of Lead}

The effect of different initial concentrations of lead alone on Acorus calamus was studied. When the initial concentration of $\mathrm{Pb}$ increased, the concentration of $\mathrm{Pb}$ in the wastewater also increased (Fig. 3). Fitting the curves in Fig. 3, it shows that the five fitting curves have a common mode that complies with the law of quadratic curve (Table 3). The lowest point of the curve is found between 27 days and 36 days. The lowest point is the lowest concentration of $\mathrm{Pb}$ in water sample and indicates that the plant has the maximum $\mathrm{Pb}$ absorption, which is the threshold of plant absorption. Because of the constant concentration of $\mathrm{Pb}$ in the environment, with the passage of time, the effect of $\mathrm{Pb}$ toxicity on plants increased. Therefore, the absorptive capacity of plants to $\mathrm{Pb}$ is weakened. P-value of the five curves are greater than 0.05 , because each sample was taken from the same group, so there is no significant difference.

The accumulation of lead in Acorus calamus and Eichhornia crassipes under two kinds of combined stress was studied. The coexistence of elements in water has a synergistic or antagonistic effect on plant absorption of heavy metals, and the concentration level of some

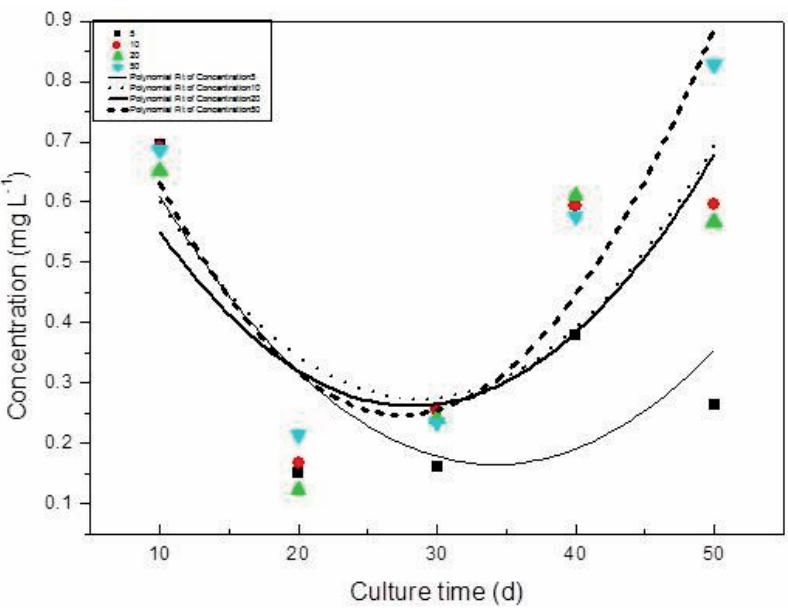

Fig. 3. When the initial concentration of lead is different, the concentration of lead in solution changes with the time of incubation. 
Table 3. Equation of fitting curve and its correlation.

\begin{tabular}{|c|c|c|c|c|}
\hline Concentration $\left(\mathrm{mg} \mathrm{L}^{-1}\right)$ & Regression equation & $\mathrm{R}^{2}$ & $\mathrm{~F}$ & $\mathrm{P}$ \\
\hline 5 & $\mathrm{y}=0.0008 \mathrm{x}^{2}-0.0519 \mathrm{x}+1.052$ & 0.6027 & 1.52 & 0.397 \\
\hline 10 & $\mathrm{y}=0.0009 \mathrm{x}^{2}-0.0535 \mathrm{x}+1.042$ & 0.5823 & 1.39 & 0.418 \\
\hline 20 & $\mathrm{y}=0.0009 \mathrm{x}^{2}-0.0493 \mathrm{x}+0.956$ & 0.5077 & 1.03 & 0.492 \\
\hline 50 & $\mathrm{y}=0.0013 \mathrm{x}^{2}-0.0693 \mathrm{x}+1.198$ & 0.8848 & 7.68 & 0.115 \\
\hline
\end{tabular}

heavy metal ions may affect the selective absorption of plants to other metal ions [36]. When Acorus calamus and Eichhornia crassipes were cultured in the waste liquid containing $\mathrm{Pb}$ and $\mathrm{Zn}$, part of the leaves started to turn yellow on the $3^{\text {rd }}$ day, and partly yellowing occurred on the $30^{\text {th }}$ day. The poisoning symptoms of Acorus calamus and Eichhornia crassipes were worse than those living under $\mathrm{Pb}$ alone contaminated solution. Therefore, there is a synergistic effect of the combined toxicity of $\mathrm{Zn}$ and $\mathrm{Pb}$ on plants. The changes of $\mathrm{Pb}$ concentration in the wastewater with different culture time are shown in Fig. 4. In the first 20 days, the Acorus calamus (Fig. 4a) showed higher initial $\mathrm{Zn}$ concentration and slower absorption rate of $\mathrm{Pb}$, which is caused by toxic synergistic effects. The concentration of $\mathrm{Pb}$ in all $\mathrm{Pb}-\mathrm{Zn}$ combined contaminated water samples was almost 0 when grown to 40 days. For Eichhornia crassipes (Fig. 4b), the concentration of $\mathrm{Pb}$ in all $\mathrm{Pb}$ Zn combined contaminated water samples was almost 0 on the $10^{\text {th }}$ day of the culture. This experiment shows that the existence of $\mathrm{Zn}$ in the wastewater promotes the absorption of $\mathrm{Pb}$, and Eichhornia crassipes has better absorption ability of $\mathrm{Pb}$ than Acorus calamus.

The Acorus calamus and Eichhornia crassipes were cultivated in wastewater containing $\mathrm{Pb}$ and EDTA. On the $3^{\text {rd }}$ day, the leaves of the plants started to turn yellow, and partly yellowing occurred on the $30^{\text {th }}$ day. Compared with the $\mathrm{Pb}$ alone stress, the poisoning symptoms of Acorus calamus and Eichhornia crassipes were alleviated in Pb-EDTA combined stress. Therefore, the combined toxicity of EDTA and $\mathrm{Pb}$ showed antagonistic effects on plants. Fig. 4 shows the concentration of $\mathrm{Pb}$
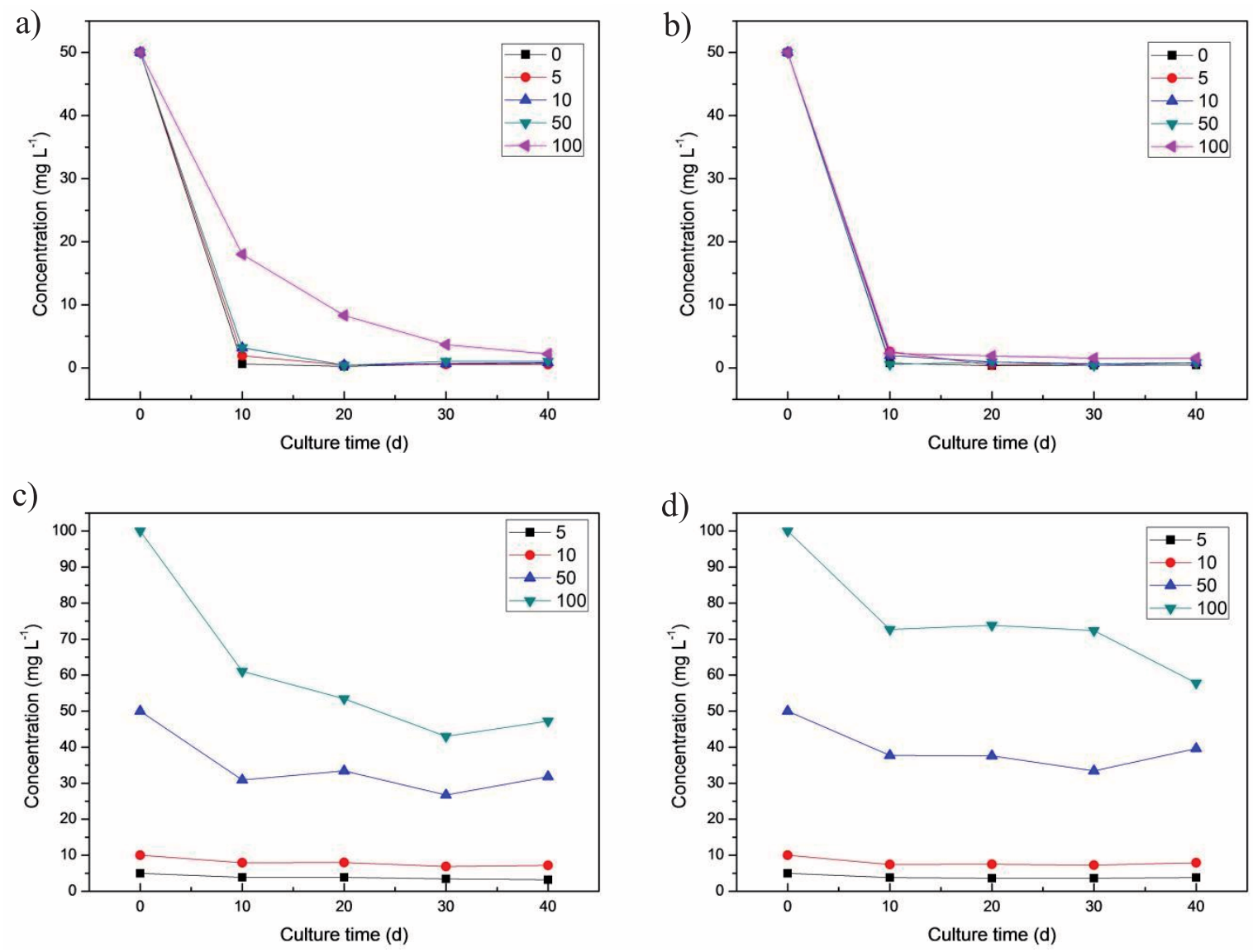

Fig. 4. The concentration of lead in combined stress changed with the culture time: a) Acorus calamus in Pb-Zn, b) Eichhornia crassipes in Pb-Zn, c) Acorus calamus in Pb-EDTA and d) Eichhornia crassipes in Pb-EDTA. 
changing in the wastewater at different culture times. Both Acorus calamus (Fig. 4c) and Eichhornia crassipes (Fig. 4d) showed that the concentration of EDTA and $\mathrm{Pb}$ has a positive relationship. When the initial concentrations of EDTA and $\mathrm{Pb}$ were both $50 \mathrm{mg} / \mathrm{L}$, after 40 days cultivation, $\mathrm{Pb}$ concentration in Acorus calamus and Eichhornia crassipes culture solution was still close to $50 \mathrm{mg} / \mathrm{L}$. Compared with the experimental groups of $\mathrm{Pb}$ alone stress and $\mathrm{Pb}-\mathrm{Zn}$ combined stress, the experimental group of Pb-EDTA combined stress absorbed more slowly, and other experimental groups of $\mathrm{Pb}$-EDTA with different initial concentrations showed the same trend. Therefore, the presence of EDTA inhibits the uptake of $\mathrm{Pb}$ by plants. Adding exogenous EDTA does not always promote plant uptake [37]. Tian et al. [38] reported that although Pb-EDTA complex was detected in Sedum alfredii plants after adding EDTA, it significantly reduced the accumulation of lead in plant roots, stems and leaves. Anning et al. [39] studied the effects of soil amendments EDTA and $\mathrm{Al}_{2}\left(\mathrm{SO}_{4}\right)_{3}$ on plant uptake of heavy metals. The results showed that EDTA inhibited plants roots absorption ability of $\mathrm{Pb}$. The results of this study are consistent with these studies.

\section{Lead Enrichment Capacity of Different Plant Species}

According to the $\mathrm{Pb}$ level measured from aboveground, underground parts and culture solution after 60 days cultivation, the enriched and transferred proportion of $\mathrm{Pb}$ was calculated (Table 4). For lead-alone stress, the TFs of the three plants were all less than 1 , which showed that all three plant species were nonhyperaccumulator species. These plants stored heavy metals in their underground tissues, which were not suitable for plant extraction. They can be recommended for plant stabilization in lead-polluted water [40, 41]. The TFs show Acorus calamus $>$ Iris tectorum $>$ Eichhornia crassipes. For Eichhornia crassipes, the overall transfer coefficient is very small, which indicates that it cannot transfer the heavy metals in the underground parts to the aboveground parts effectively. The BCFs of the underground parts is greater than the aboveground parts. The BCFs of the underground parts show Eichhornia crassipes $>$ Acorus calamus $>$ Iris tectorum. The BCFs of the aboveground parts show Acorus calamus $>$ Eichhornia crassipes $>$ Iris tectorum. For Acorus calamus and Eichhornia crassipes, the BCFs of the underground parts increased gradually with the increase of $\mathrm{Pb}$ concentration in solution at the mediumlow concentration $(\leq 50 \mathrm{mg} / \mathrm{L})$, which indicated that lead mainly enters into plant roots after entering the plants. This may be a result of self-protection mechanism of plants. It tries to prevent the transfer of $\mathrm{Pb}$ from roots to stems and leaves, and to avoid its influence on photosynthesis and metabolism [42].

Table 5 shows the BCFs and TFs of Acorus calamus and Eichhornia crassipes under different concentration gradients under the effects of two combined stresses. The BCFs of the underground parts were greater than aboveground parts for both plants. For plants living in $\mathrm{Pb}$ $\mathrm{Zn}$-contaminated solution, the $\mathrm{Pb}$ absorption capacity of

Table 4. Enrichment and transfer of lead by different plants.

\begin{tabular}{|c|c|c|c|c|}
\hline \multirow{2}{*}{ Aquatic plants } & \multirow{2}{*}{$\begin{array}{l}\text { Concentration } \\
\left(\mathrm{mg} \mathrm{L}^{-1}\right)\end{array}$} & \multicolumn{2}{|c|}{ BCFs } & \multirow{2}{*}{ TFs } \\
\hline & & Aboveground parts & Underground parts & \\
\hline \multirow{6}{*}{ Acorus calamus } & 5 & 9.22 & 30.82 & 0.30 \\
\hline & 10 & 9.04 & 65.66 & 0.14 \\
\hline & 50 & 6.27 & 87.28 & 0.07 \\
\hline & 100 & 14.79 & 21.47 & 0.69 \\
\hline & 500 & 0.78 & 1.94 & 0.40 \\
\hline & mean & 8.02 & 41.43 & 0.32 \\
\hline \multirow{6}{*}{ Eichhornia crassipes } & 5 & 1.49 & 154.75 & 0.01 \\
\hline & 10 & 1.75 & 555.56 & $<0.01$ \\
\hline & 50 & 1.80 & 602.18 & $<0.01$ \\
\hline & 100 & 1.55 & 198.43 & 0.01 \\
\hline & 500 & 0.42 & 4.31 & 0.10 \\
\hline & mean & 1.40 & 303.05 & 0.02 \\
\hline \multirow{6}{*}{ Iris tectorum } & 5 & 1.71 & 2.57 & 0.67 \\
\hline & 10 & 1.24 & 46.35 & 0.03 \\
\hline & 50 & 0.44 & 18.09 & 0.02 \\
\hline & 100 & 1.48 & 69.05 & 0.02 \\
\hline & 500 & 0.04 & 8.52 & $<0.01$ \\
\hline & mean & 0.98 & 28.92 & 0.15 \\
\hline
\end{tabular}


Table 5. Enrichment and transfer of Acorus calamus and Eichhornia crassipes under combined pollution.

\begin{tabular}{|c|c|c|c|c|c|}
\hline \multirow{2}{*}{$\begin{array}{l}\text { Combined } \\
\text { pollution }\end{array}$} & \multirow{2}{*}{ Aquatic plants } & \multirow{2}{*}{$\begin{array}{l}\text { Concentration } \\
\left(\mathrm{mg} \mathrm{L}^{-1}\right)\end{array}$} & \multicolumn{2}{|c|}{ BCFs } & \multirow{2}{*}{ TFs } \\
\hline & & & Aboveground parts & Underground parts & \\
\hline \multirow{12}{*}{$\begin{array}{c}\mathrm{Pb}-\mathrm{Zn} \text { com- } \\
\text { bined pollution }\end{array}$} & \multirow{6}{*}{ Acorus calamus } & 0 & 8.96 & 11.79 & 0.76 \\
\hline & & 5 & 6.23 & 8.61 & 0.72 \\
\hline & & 10 & 6.56 & 94.47 & 0.07 \\
\hline & & 50 & 11.00 & 79.60 & 0.14 \\
\hline & & 100 & 6.78 & 2.22 & 3.06 \\
\hline & & mean & 7.90 & 39.33 & 0.95 \\
\hline & \multirow{6}{*}{ Eichhornia crassipes } & 0 & 1.80 & 602.18 & $<0.01$ \\
\hline & & 5 & 10.46 & 180.34 & 0.06 \\
\hline & & 10 & 1.47 & 66.36 & 0.02 \\
\hline & & 50 & 2.57 & 176.87 & 0.01 \\
\hline & & 100 & 18.80 & 193.94 & 0.10 \\
\hline & & mean & 7.02 & 243.94 & 0.04 \\
\hline \multirow{12}{*}{$\begin{array}{l}\text { Pb-EDTA com- } \\
\text { bined pollution }\end{array}$} & \multirow{6}{*}{ Acorus calamus } & 0 & 5.77 & 92.80 & 0.06 \\
\hline & & 5 & 4.98 & 5.05 & 0.99 \\
\hline & & 10 & 2.87 & 2.19 & 1.31 \\
\hline & & 50 & 0.31 & 1.45 & 0.21 \\
\hline & & 100 & 0.23 & 1.20 & 0.19 \\
\hline & & mean & 2.83 & 20.54 & 0.55 \\
\hline & \multirow{6}{*}{ Eichhornia crassipes } & 0 & 6.72 & 4.97 & 1.35 \\
\hline & & 5 & 0.40 & 6.78 & 0.06 \\
\hline & & 10 & 0.10 & 1.89 & 0.05 \\
\hline & & 50 & 0.02 & 2.61 & 0.01 \\
\hline & & 100 & 0.32 & 1.96 & 0.16 \\
\hline & & mean & 1.51 & 3.64 & 0.33 \\
\hline
\end{tabular}

In the case of combined pollution, when the concentration of $\mathrm{Pb}, \mathrm{Zn}$ and EDTA in the solution is $500 \mathrm{mg} / \mathrm{L}$, the phenomenon of decay and death of aquatic plants cannot be measured and not listed in the table.

the Eichhornia crassipes underground parts was greater than that of the Acorus calamus. For those living in $\mathrm{Pb}$ EDTA-contaminated solution, the absorption capacity of $\mathrm{Pb}$ of Acorus calamus aboveground and underground parts was greater than Eichhornia crassipes. Overall, the average $\mathrm{BCFs}$ of aboveground and underground parts of both plants showed $\mathrm{Pb}-\mathrm{Zn}$ combined stress $>$ Pb-EDTA combined stress. The TFs of Acorus calamus were higher than Eichhornia crassipes under the two combined stress states. The analysis shows that Acorus calamus has better ability in transferring heavy metals than Eichhornia crassipes.

Table 6 lists the BCFs, TFs and $\mathrm{K}_{\mathrm{pb}}$ of two combined stress states when the concentrations of $\mathrm{Zn}$ and EDTA were changed under the initial concentration of $\mathrm{Pb}$ of $10 \mathrm{mg} / \mathrm{L}$. The average BCFs of aboveground and underground parts showed $\mathrm{Pb}-\mathrm{Zn}$ combined stress $>$ $\mathrm{Pb}$ alone stress $>\mathrm{Pb}$-EDTA combined stress, which proved that the combined toxicity of $\mathrm{Zn}$ and $\mathrm{Pb}$ on a plant has a synergistic effect; and combined toxicity of EDTA and $\mathrm{Pb}$ showed an antagonistic effect on plants.
For $\mathrm{K}_{\mathrm{pb}}$, the $\mathrm{K}_{\mathrm{pb}}$ of the underground parts under $\mathrm{Pb}$ $\mathrm{Zn}$ combined stress is greater than the aboveground parts; the aboveground parts under Pb-EDTA combined stress is larger than the underground parts. The $\mathrm{K}_{\mathrm{pb}}$ of the aboveground parts is greater than 1 . These results show that EDTA can increase the transfer ability of $\mathrm{Pb}$ from underground parts to aboveground parts. Wu et al. [43] research also showed that EDTA had a significant impact on increasing the concentrations of $\mathrm{Cu}$ and $\mathrm{Pb}$ in aboveground parts. The results of this study are similar to those reported.

\section{Conclusions}

Remediation of heavy metal pollution in water has become an urgent problem to be solved. The study shows that the existence of a certain concentration of $\mathrm{Pb}$ inhibits the growth of the roots and causes a yellowing effect on plant leaves. Double factor variance analysis showed that culture time, $\mathrm{Pb}$ concentration, and plant 
Table 6. Enrichment and transfer of lead by Acorus calamus under different pollution conditions.

\begin{tabular}{|c|c|c|c|c|c|c|}
\hline \multirow{2}{*}{ Pollution } & \multirow{2}{*}{$\begin{array}{l}\text { Concentration } \\
\left(\mathrm{mg} \mathrm{L}^{-1}\right)\end{array}$} & \multicolumn{2}{|c|}{ BCFs } & \multirow{2}{*}{ TFs } & \multicolumn{2}{|c|}{$\mathrm{K}_{\mathrm{pb}}$} \\
\hline & & Aboveground parts & Underground parts & & Aboveground parts & Underground parts \\
\hline \multirow{5}{*}{$\begin{array}{l}\text { Single } \mathrm{Pb} \\
\text { pollution }\end{array}$} & 5 & 9.22 & 30.82 & 0.30 & - & - \\
\hline & 10 & 9.04 & 65.66 & 0.14 & - & - \\
\hline & 20 & 6.31 & 78.45 & 0.08 & - & - \\
\hline & 50 & 6.27 & 87.28 & 0.07 & - & - \\
\hline & mean & 7.71 & 65.55 & 0.15 & - & - \\
\hline \multirow{6}{*}{$\begin{array}{l}\mathrm{Pb}-\mathrm{Zn} \text { combined } \\
\text { pollution }\end{array}$} & 0 & 13.27 & 65.66 & 0.20 & - & - \\
\hline & 5 & 5.76 & 110.06 & 0.05 & 0.04 & 1.29 \\
\hline & 10 & 38.08 & 68.27 & 0.56 & 0.25 & 0.70 \\
\hline & 20 & 7.79 & 111.93 & 0.07 & 0.03 & 0.71 \\
\hline & 50 & 4.89 & 287.27 & 0.02 & 0.03 & 2.55 \\
\hline & mean & 13.96 & 128.64 & 0.18 & 0.09 & 1.31 \\
\hline \multirow{6}{*}{$\begin{array}{l}\text { Pb-EDTA } \\
\text { combined } \\
\text { pollution }\end{array}$} & 0 & 13.27 & 65.66 & 0.02 & - & - \\
\hline & 5 & 3.45 & 13.31 & 0.26 & 4.00 & 0.37 \\
\hline & 10 & 1.52 & 6.42 & 0.24 & 4.89 & 0.50 \\
\hline & 20 & 1.30 & 2.07 & 0.63 & 1.30 & 0.20 \\
\hline & 50 & 0.68 & 2.22 & 0.31 & 2.34 & 0.18 \\
\hline & mean & 4.04 & 17.94 & 0.29 & 3.13 & 0.31 \\
\hline
\end{tabular}

species have significant effects on the enrichment of lead by aquatic plants. The study on the enrichment ability of lead of aquatic plants under single stress and combined stress shows that the absorption of lead by Acorus calamus and Eichhornia crassipes in three aquatic plants is better. According to the growth of aquatic plants and the absorption of lead, Acorus calamus is suitable for the treatment of lead-containing wastewater at medium-low concentrations, and Eichhornia crassipes has a better effect on treating wastewater that has a high concentration of lead compared to Acorus calamus and Iris tectorum. There is a threshold for the absorption of lead by aquatic plants. When the lead content in plants exceeds a certain threshold, it affects plant growth and metabolism. The combined toxicity of $\mathrm{Zn}$ and $\mathrm{Pb}$ on plants is synergistic. Although the combined toxicity of EDTA and Pb had an antagonistic effect on plants, EDTA can promote plants to transfer lead from underground to aboveground parts. The BCFs of the underground parts of the aquatic plant were much larger than the BCFs in the aboveground parts, and almost all TFs were less than 1, which indicated that the lead in the wastewater was mainly absorbed by the roots after it enters the plant. The Eichhornia crassipes had the best ability in enrichment of lead with lightest symptoms existing. Acorus calamus had the best ability of transferring the lead. Therefore, the high biomass of Eichhornia crassipes and Acorus calamus, as well as the high tolerance to lead, make it possible to effectively repair lead-contaminated wastewater, which can be used as a selection species for phytoremediation.

\section{Acknowledgements}

This study was supported by the National Major Program of Water Pollution Control and Treatment Technology of China (2014ZX07201-011-002) and the Provincial Innovation Training Project of Southwest University for Nationalities (S201610656094).

\section{Conflict of Interest}

The authors declare no conflict of interest.

\section{References}

1. REZANIA S., TAIB S.M., DIN M.F.M., DAHALAN F.A., KAMYAB H. Comprehensive review on phytotechnology: Heavy metals removal by diverse aquatic plants species from wastewater. Journal of Hazardous Materials. 318, 587, 2016.

2. DIXIT R., WASIULLAH, MALAVIYA D., PANDIYAN K., SINGH U.B., SAHU A., SHUKLA R., SINGH B.P., RAI J.P., SHARMA P.K., LADE H., PAUL D. Bioremediation of Heavy Metals from Soil and Aquatic Environment: An Overview of Principles and Criteria of Fundamental Processes. Sustainability. 7 (2), 2189, 2015.

3. GILL L.W., RING P., CASEY B., HIGGINS N.M.P., JOHNSTON P.M. Long term heavy metal removal by a constructed wetland treating rainfall runoff from a motorway. Science of the Total Environment. 601, 32, 2017.

4. YAN L., LI L., NI X., LI C., LI J. Accumulation of Soil Heavy Metals in Five Species of Wetland Plants. 
Acta Botanica Boreali-Occidentalia Sinica. 36 (10), 2078, 2016.

5. CICERO-FERNÁNDEZ D., PEÑA-FERNÁNDEZ M., EXPÓSITO-CAMARGO J.A., ANTIZAR-LADISLAO B. Long-term (two annual cycles) phytoremediation of heavy metal-contaminated estuarine sediments by Phragmites australis. New Biotechnology. 38, 56, 2017.

6. BERNARDINO C.A.R., MAHLER C.F., PREUSSLER K.H., NOVO L.A.B. State of the Art of Phytoremediation in Brazil - Review and Perspectives. Water Air and Soil Pollution. 227 (8), 272, 2016.

7. SINGH A., PRASAD S.M. Remediation of heavy metal contaminated ecosystem: an overview on technology advancement. International Journal of Environmental Science and Technology. 12 (1), 353, 2015.

8. ROMEH A.A., KHAMIS M.A., METWALLY S.M. Potential of Plantago major L. for Phytoremediation of Lead-Contaminated Soil and Water. Water Air and Soil Pollution. 227 (1), 9, 2016.

9. GAUR N., FLORA G., YADAV M., TIWARI A. A review with recent advancements on bioremediationbased abolition of heavy metals. ENVIRONMENTAL SCIENCE-PROCESSES \& IMPACTS. 16 (2), 180, 2014.

10. PAN Y., WANG H., GU Z., XIONG G., YI F. Accumulation and translocation of heavy metals by macrophytes. Acta Ecologica Sinica. 30 (23), 6430, 2010.

11. ALI H., KHAN E., SAJAD M.A. Phytoremediation of heavy metals - Concepts and applications. Chemosphere. 91 (7), 869, 2013.

12. LI J., LUAN Y., SUN X., YU H., QI N., WU X. Research Advances in Remediation of Heavy Metal Contaminated Water Bodies by Aquatic Plants. World Forestry Research. 28 (2), 31, 2015.

13. LI N., LI Z., FU Q., ZHUANG P., GUO B., LI H. Agricultural Technologies for Enhancing the Phytoremediation of Cadmium-Contaminated Soil by Amaranthus hypochondriacus L. Water Air and Soil Pollution. 224 (9), 1673, 2013.

14. MAHAR A., WANG P., ALI A., AWASTHI M.K., LAHORI A.H., WANG Q., LI R., ZHANG Z. Challenges and opportunities in the phytoremediation of heavy metals contaminated soils: A review. Ecotoxicology and Environmental Safety. 126, 111, 2016.

15. SOUZA L.A., PIOTTO F.A., NOGUEIROL R.C., AZEVEDO R.A. Use of non-hyperaccumulator plant species for the phytoextraction of heavy metals using chelating agents. Scientia Agricola. 70 (4), $290,2013$.

16. BOECHAT C.L., PISTÓIA V.C., GIANELO C., CAMARGO F.A.O. Accumulation and translocation of heavy metal by spontaneous plants growing on multimetal-contaminated site in the Southeast of Rio Grande do Sul state, Brazil. Environmental Science and Pollution Research. 23 (3), 2371, 2016.

17. CHIRAKKARA R.A., CAMESELLE C., REDDY K.R. Assessing the applicability of phytoremediation of soils with mixed organic and heavy metal contaminants. Reviews in Environmental Science and Bio/Technology. 15 (2), 299, 2016.

18. GALAL T.M., GHARIB F.A., GHAZI S.M., MANSOUR K.H. Metal uptake capability of Cyperus articulatus L. and its role in mitigating heavy metals from contaminated wetlands. Environmental Science and Pollution Research. 24 (27), 21636, 2017.

19. BONANNO G., CIRELLI G.L. Comparative analysis of element concentrations and translocation in three wetland congener plants: Typha domingensis, Typha latifolia and
Typha angustifolia. Ecotoxicology and Environmental Safety. 143, 92, 2017.

20. BINGÖL N.A., ÖZMAL F., AKIN B. Phytoremediation and Biosorption Potential of Lythrum salicaria L. for Nickel Removal from Aqueous Solutions. Polish Journal of Environmental Studies. 26 (6), 2479, 2017.

21. LU D., HUANG Q., DENG C., ZHENG Y. Phytoremediation of Copper Pollution by Eight Aquatic Plants. Polish Journal of Environmental Studies. 27 (1), 175, 2018.

22. LI J., DU Z., ZOU C., DAI Z., DU D., YAN C. The mutual restraint effect between the expansion of Alternanthera philoxeroides (Mart.) Griseb and cadmium mobility in aquatic environment. Ecotoxicology and Environmental Safety. 148, 237, 2018.

23. DOGAN M., KARATAS M., AASIM M. Cadmium and lead bioaccumulation potentials of an aquatic macrophyte Ceratophyllum demersum L.: A laboratory study. Ecotoxicology and Environmental Safety. 148, 431, 2018.

24. MAHDAVIAN K., GHADERIAN S.M., TORKZADEHMAHANI M. Accumulation and phytoremediation of $\mathrm{Pb}, \mathrm{Zn}$, and $\mathrm{Ag}$ by plants growing on Koshk lead - zinc mining area, Iran. Journal of Soils and Sediments. 17 (5), 1310, 2017.

25. ZHANG Y., YIN C., CAO S., CHENG L., WU G., GUO J. Heavy metal accumulation and health risk assessment in soil-wheat system under different nitrogen levels. Science of the Total Environment. 622, 1499, 2018.

26. PAPAZOGLOU E.G., FERNANDO A.L. Preliminary studies on the growth, tolerance and phytoremediation ability of sugarbeet (Beta vulgaris L.) grown on heavy metal contaminated soil. Industrial Crops \& Products. 107, 463, 2017.

27. FENG J., LIN Y., YANG Y., SHEN Q., HUANG J., WANG S., ZHU X., LI Z. Tolerance and bioaccumulation of $\mathrm{Cd}$ and $\mathrm{Cu}$ in Sesuvium portulacastrum. Ecotoxicology and Environmental Safety. 147, 306, 2018.

28. PATEK-MOHD N., ABDU A., JUSOP S., ABDULHAMID H., KARIM M., NAZRIN M., AKBAR M., JAMALUDDIN A.S. Potentiality of Melastoma malabathricum as Phytoremediators of soil contaminated with sewage sludge. Scientia Agricola. 75 (1), 27, 2018.

29. RETAMAL-SALGADO J., HIRZEL J., WALTER I., MATUS J. Bioabsorption and Bioaccumulation of Cadmium in the Straw and Grain of Maize (Zea mays L.) in Growing Soils Contaminated with Cadmium in Different Environment. International Journal of Environmental Research and Public Health. 14 (11), 1399, 2017.

30. PÉREZ-SIRVENT C., HERNÁNDEZ-PÉREZ C., MARTÍNEZ-SÁNCHEZ M.J., GARCÍA-LORENZO M.L., BECH J. Metal uptake by wetland plants: implications for phytoremediation and restoration. Journal of Soils and Sediments. 17 (5), 1384, 2017.

31. CHANU L.B., GUPTA A. Phytoremediation of lead using Ipomoea aquatica Forsk. in hydroponic solution. Chemosphere. 156, 407, 2016.

32. FU J., HAN Y., LI Y., XU M. Effects of single and combined stresses of $\mathrm{Pb}, \mathrm{Cd}$ on growth and some physiological indexes of Ins ensata var.hortensis seedling. Journal of Plant Resources and Environment. 19 (3), 23, 2010.

33. YANG G., WU J., TANG Y. Research advances in plant resistance mechanisms under lead stress. Chinese Journal of Ecology. 24 (12), 1507, 2005. 
34. ZHANG J. Studies on leaf yellowing disease for Huanghua pear plants on saline-alkaline soil. Soil and Fertilizer Sciences in China. (4), 50-53, 2011.

35. LIN F., CONG X., HUANG J., CHEN Q. Resistance of artificial wetland plants to lead. Chinese Journal of Environmental Engineering. 8 (6), 2329, 2014.

36. JIANG X., WEN C., CAO S., CHENG G. Research progress on the phytoremediation of water bodies contaminated by heavy metals. Applied Chemical Industry. 45 (10), 1982, 2016.

37. DUAN D., YU M., SHI J. Research advances in uptake, translocation, accumulation and detoxification of $\mathrm{Pb}$ in plants. The journal of applied ecology. 25 (1), 287, 2014.

38. TIAN S., LU L., YANG X., HUANG H., BROWN P., LABAVITCH J., LIAO H., HE Z. The impact of EDTA on lead distribution and speciation in the accumulator Sedum alfredii by synchrotron X-ray investigation. Environmental Pollution. 159 (3), 782, 2011.

39. ANNING A.K., AKOTO R. Assisted phytoremediation of heavy metal contaminated soil from a mined site with Typha latifolia and Chrysopogon zizanioides. Ecotoxicology and Environmental Safety. 148, 97, 2018.
40. JEELANI N., YANG W., XU L., QIAO Y., AN S., LENG X. Phytoremediation potential of Acorus calamus in soils cocontaminated with cadmium and polycyclic aromatic hydrocarbons. Scientific Reports. 7 (1), 8028, 2017.

41. HESAMI R., SALIMI A., GHADERIAN S.M. Lead, zinc, and cadmium uptake, accumulation, and phytoremediation by plants growing around Tang-e Douzan lead-zinc mine, Iran. Environmental Science and Pollution Research. 25 (9), 8701, 2018

42. HUANG G.Y., WANG Y.S. Physiological and biochemical responses in the leaves of two mangrove plant seedlings (Kandelia candel and Bruguiera gymnorrhiza) exposed to multiple heavy metals. Journal of Hazardous Materials. 182 (1-3), 848, 2010.

43. WU L.H., LUO Y.M., XING X.R., CHRISTIE P. EDTA-enhanced phytoremediation of heavy metal contaminated soil with Indian mustard and associated potential leaching risk. Agriculture Ecosystems \& Environment. 102, 307, 2004. 